\title{
Piotr Sniedziewski
}

M. Loba, Wokół narracyjnego zwrotu. Szkice krytyczne, Wydawnictwo Naukowe UAM, Poznań 2013

\section{Pragnienie opowieści}

ABSTRACT. Śniedziewski Piotr, Pragnienie opowieści [Desire for stories]. „Przestrzenie Teorii” 23. Poznań 2015, Adam Mickiewicz University Press, pp. 274-283. ISBN 978-83-232-2920-9. ISSN 1644-6763. DOI 10.14746/pt.2015.23.17.

The aim of this article is to discuss Mirosław Loba's book titled Wokó narracyjnego zwrotu. Szkice krytyczne [Around the Narrative Turn: Critical Essays]. The book is a reconstruction of the main trends in contemporary French thought on narrative (the psychoanalytic approach and Paul Ricœur's concept are particularly emphasized). Loba's theoretical perspective is complemented by analytical attempts - the researcher interprets Andrea Camilleri's and Donna Leon's criminal novels and he also proposes one of the most interesting Polish interpretations of Jonathan Little's The Kindly Ones.

Wśród dość licznych rozpraw, które w ostatnich latach ukazały się w Polsce i poświęcone zostały teorii narracji ${ }^{1}$, książka Mirosława Loby zatytułowana Wokót narracyjnego zwrotu. Szkice krytyczne ${ }^{2}$ zasługuje na szczególną uwagę z co najmniej dwóch powodów. Po pierwsze, jest to praca, w której w sposób kompetentny omówione zostały główne nurty francuskiej refleksji nad narracją (zwłaszcza te inspirowane psychoanalizą). Autor w przekonujący sposób porządkuje różne ujęcia, dokonuje porównań i podsumowań, dzięki czemu do rąk czytelnika trafia bezcenny przewodnik: rzecz warta podkreślenia, ponieważ Loba - jako romanista sięga po prace oryginalne (często tłumaczy wybrane fragmenty), a nie zawierza przekładom bądź wyrwanym z macierzystego kontekstu uwagom, co jest dość częstym mankamentem współczesnych polskich prac

1 Zob. np. Narracja jako sposób rozumienia świata, red. J. Trzebiński, Gdańsk 2003; K. Rosner, Narracja, tożsamość i czas, Kraków 2003 (wyd. II - 2006); Narracja i tożsamość. (1) Narracje w kulturze oraz Narracja i tożsamość. (2) Antropologiczne problemy literatury - oba tomy pod red. W. Boleckiego, R. Nycza, Warszawa 2004; H. Seweryniak, Prorok i błazen. Szkice z teologii narracji, Poznań 2005; Narracja. Teoria i praktyka, red. B. Janusz, K. Gdowska, B. de Barbaro, Kraków 2008.

2 M. Loba, Wokót narracyjnego zwrotu. Szkice krytyczne, Poznań 2013. Kolejne cytaty z książki lokalizuję w tekście głównym, wskazując w nawiasie numer strony. 
odwołujących się do francuskich teorii ${ }^{3}$. Po drugie, Loba umiejętnie wykorzystuje zreferowane ujęcia narracji do celów analitycznych, dzięki czemu rozdziały teoretyczne sąsiadują w książce $\mathrm{z}$ finezyjnymi interpretacjami (badacz sięga np. po kryminalne powieści Andrei Camilleriego oraz Donny Leon, proponuje nam również jedno z najciekawszych polskich odczytań Easkawych Jonathana Littela).

Loba, w znamiennie zatytułowanym wprowadzeniu do książki (Narracyjny zwrot: poznanie, etyka, ideologia), deklaruje, iż jego celem nie jest powrót do dobrze znanych i przez długi czas dominujących ujęć narracji strukturalistycznego ${ }^{4}$ oraz komunikacyjnego. Interesuje go bowiem inne podejście: „Chodzi tutaj przede wszystkim o inspirowaną psychoanalizą refleksję nad potrzebą i pragnieniem tworzenia opowieści, nad koniecznością konfigurowania ludzkiego doświadczenia w fabułę" (s. 9). Loba stwierdza tym samym, że pojęcie narracji nie ogranicza się do określenia jej językowego charakteru, że trudno wyczerpująco i wiarygodnie opisać narrację jako zbiór różnych schematów czy modeli opowiadania, ponieważ jest ona czymś więcej - jest sposobem istnienia człowieka w świecie, konstytuowania ludzkiego ,ja” i rozumienia otaczającej to ,ja” rzeczywistości. Intrygująco pisał już o tym, choć wychodząc z innych niż Loba założeń, Tzvetan Todorov. W artykule o ludziach-opowieściach (les hommes-

${ }^{3}$ Moim celem nie jest tu piętnowanie wspomnianych prac, a jedynie podkreślenie badawczej rzetelności Loby oraz zwrócenie uwagi na istotny - jak sądzę - problem związany z tłumaczeniem oraz z recepcją francuskiej myśli poststrukturalnej w Polsce. Na ten temat zob. m.in. „French Theory” w Polsce, red. E. Domańska, M. Loba, Poznań 2010.

${ }_{4}^{4}$ Wśród niewielu rzeczy, które w książce Wokót narracyjnego zwrotu wywołują zastrzeżenia czytelnika, wymienić należy stosunek Loby do strukturalizmu. Badacz przyznaje, że we francuskiej teorii ten nurt myślenia stanowił swego rodzaju przełom, a dyskusja z metodologicznymi założeniami strukturalizmu doprowadziła do narodzin różnych nowoczesnych ujęć narracji. Tymczasem w Polsce rzecz wygląda według autora książki odmiennie: „W Polsce zaś, gdzie strukturalizm nie stał się punktem zwrotnym w humanistyce, dyskusja z nim nie miała tak przełomowego charakteru jak we Francji. Toteż wywodząca się ze strukturalistycznej tradycji nowoczesna refleksja nad narracją toczy się u nas własnymi drogami, gdzieś na obrzeżach światowych sporów" (s. 14). Przede wszystkim sądzę, że strukturalizm odegrał w polskiej teorii rolę większą od tej, którą chciałby mu przypisać poznański badacz. Przypomnijmy, że zdaniem A. Burzyńskiej polscy strukturaliści „stworzyli [...] w latach siedemdziesiątych i osiemdziesiątych najprężniejszą w dziejach polskiego literaturoznawstwa szkołę teoretyczną zajmującą się badaniami nad komunikowaniem literatury. [...] W pracach strukturalistów pojawiły się też jedne z najważniejszych terminów powojennej polskiej teorii literatury" (A. Burzyńska, M.P. Markowski, Teorie literatury XX wieku. Podręcznik, Kraków 2007, s. 293). Co więcej, to właśnie polscy strukturaliści (a także ich uczniowie, którzy - to prawda - do dorobku swych mistrzów odnosili się często krytycznie) w szczególny sposób rozwinęli teoretyczny namysł nad narracją - dość wspomnieć w tym miejscu prace K. Budzyka, S. Skwarczyńskiej, K. Bartoszyńskiego, J. Sławińskiego czy M. Głowińskiego. 
récits) teoretyk bułgarskiego pochodzenia akcentował fakt, że w historii literatury bez kłopotu odnajdujemy utwory, których głównym celem jest pochwała potęgi narracji, a potrzeba snucia opowieści okazuje się w nich bardziej wyrazista niż psychologiczny rysunek postaci. Jako przykłady takich właśnie opowieści Todorov wymienia Odyseję, Dekameron, Baśnie $z$ tysiaca $i$ jednej nocy oraz Rękopis znaleziony $w$ Saragossie 5 . W związku z Baśniami... Todorov, analizując szkatułkową konstrukcję tego dzieła, podkreśla: „Nic nie może się wymknąć ze świata narracji, który obejmuje całość doświadczenia”6. Zaś nieco dalej dodaje: „Jeśli postaci [w Baśniach...] nie przestają opowiadać historii, oznacza to, iż ten akt ma szczególne znaczenie: opowiadać, znaczy żyć. [...] Biała strona jest zatruta. Książka, która nie opowiada żadnej historii, zabija. Brak opowiadania oznacza śmierć"7.

Nakreśloną opozycję (między narracją rozumianą bardzo wąsko - jako pewien językowy schemat opowiadania - a narracją stającą się jednym $\mathrm{z}$ elementów ludzkiego istnienia) możemy według Loby dostrzec w ewolucji poglądów na narrację Rolanda Barthes'a, manifestowaną „nieśmiało" (s. 15), jak pisze poznański badacz, już w artykule poświęconym

5 Zob. T. Todorov, Les hommes-récits, [w:] tenże, Poétique de la prose, Paris 1971, s. 78-91. Chciałbym - na marginesie uwag poświęconych artykułowi Les hommes-récits podkreślić, że nie do końca podzielam pojawiające się w książce Loby ogólne sądy poświęcone teoretykom, którzy nie stali się głównymi bohaterami jego pracy. Tak właśnie rzecz wygląda w przypadku Todorova - różne drogi jego poszukiwań Loba zamyka w stwierdzeniu, mówiącym, iż „opisywał [on] strukturalne właściwości literatury fantastycznej i próbował stworzyć gramatykę Dekameronu, jednak dość szybko rozsta[ł] się ze strukturalizmem i przedmiotem jego zainteresowań sta[ła] się historia humanizmu” (s. 17). To prawda, że Todorov zasłynął jako autor rozpraw strukturalistycznych - Loba słusznie czyni więc w tym miejscu aluzję do Grammaire du „Décaméron” z 1969 oraz do Introduction à la littérature fantastique z 1970. Jednak nim ukazały się późniejsze książki Todorova, sytuujące się w kręgu historii humanizmu (można tu wspomnieć np. rozprawy Éloge du quotidien: essai sur la peinture hollandaise du XVII ${ }^{e}$ siècle z 1993 czy Le jardin imparfait: la pensée humaniste en France z 1998 - tekst przełożony na język polski i wydany w 2003), niejednokrotnie udawało mu się przekroczyć horyzont dogmatycznie rozumianego strukturalizmu - choćby w przywoływanym przeze mnie szkicu Les hommes-récits czy w nieco późniejszej, bo z roku 1977, książce Théories du symbole (wyd. polskie - 2011). W konsekwencji przywołana wcześniej uwaga Loby wydaje mi się nie do końca sprawiedliwa - zwłaszcza jeśli zestawimy ją np. ze szczegółową rekonstrukcją refleksji i ewolucji postaw Barthes'a, któremu autor rozprawy Wokót narracyjnego zwrotu poświęca wiele przenikliwych spostrzeżeń.

${ }^{6}$ T. Todorov, Les hommes-récits, s. 84. Także według J.L. Borgesa Baśnie... są swoistą maszyną do snucia opowieści, sprawiającą, że liczni tłumacze nie mogą oprzeć się potrzebie ich korygowania bądź uzupełniania - zob. J.L. Borges, Tłumacze „Tysiąca i jednej nocy”, [w:] tenże, Historia wieczności, przeł. A. Elbanowski, Warszawa 1995, s. 87-117.

7 T. Todorov, Les hommes-récits, s. 86-87. 
analizie strukturalnej opowiadań i opublikowanym w 1966 roku na łamach „Communications" 8 . W zakończeniu tego słynnego szkicu wybrzmiewa przeświadczenie, iż narracja to nie tylko pewna struktura, wobec której należy zachować daleko idącą nieufność i poddać ją drobiazgowemu rozbiorowi (co Barthes uczynił parę lat później w $S / Z$ ), ale także jedno z „najbardziej archaicznych doświadczeń podmiotu” (s. 15), odpowiadające jego potrzebie istnienia wobec świata i innych. Loba nie bez racji konkluduje:

Wypadałoby zatem podkreślić dwuznaczność, jaką kryje Barthesowskie [sic!] myślenie o opowiadaniu: narracja to nieunikniona, uniwersalna forma ludzkiej mowy, poddawana w literaturze zabiegom mającym na celu zburzenie jej archaicznej struktury, a z drugiej strony jest to forma pożądana, będąca swoistym obiektem pragnienia, dostarczająca różnorodnych gratyfikacji (s. 16).

W początkowej części przywołanego cytatu Barthes postrzega literaturę $\mathrm{w}$ kategoriach nieufności, prowadzącej do rozkładu tradycyjnych form i sposobów opowiadania. Co ciekawe - nieco szkoda, że Loba pomija to zagadnienie - te spostrzeżenia Barthes'a doskonale korespondują z uwagami rzeczników nouveau roman, zwłaszcza Alaina Robbe-Grilleta, bliskiego przyjaciela autora $S / Z^{9}$. Zresztą, zarówno w wymiarze ideologicznym, jak i teoriopoznawczym, wczesny strukturalizm francuski pozostawał w ścisłym związku z reprezentantami nouveau roman, co przytomnie podkreśla Nelly Wolf: „W pewnym sensie nouveau roman jest tekstem dla strukturalizmu, a strukturalizm jest dyskursem dla nouveau roman. Nouveau roman w postaci, w jakiej wyłonił się ze swych mętnych źródeł, stał się potwierdzeniem in vivo strukturalizmu. Z kolei boską niespodzianką dla nouveau roman, jego teoretycznym wyświęceniem oraz uzasadnieniem a posteriori, okazał się strukturalizm"10. Przypomnijmy więc, że Robbe-Grillet - podobnie jak inni autorzy z kręgu nouveau roman (Nathalie Sarraute czy Michel Butor) - niejednokrotnie sceptycznie i ironicznie wypowiadał się o tradycyjnych formach opowiadania oraz

8 Zob. R. Barthes, Introduction à l'analyse structurale des récits, „Communications” 1966, nr 8; por. przekład polski - R. Barthes, Wstęp do analizy strukturalnej opowiadań, przeł. W. Błońska, „Pamiętnik Literacki” 1968, z. 4.

9 Dowodem bliskiej przyjaźni Barthes'a i Robbe-Grilleta jest choćby wydana przez tego drugiego książka Pourquoi j’aime Barthes, Paris 1978. Warto też podkreślić, że Barthes poświęcił Robbe-Grilletowi kilka błyskotliwych esejów, wśród nich: Littérature objective, „Critique” 1954, nr 10 (szkic przedrukowany w Essais critiques, Paris 1964). Na ten temat zob. m.in. R.L. Bogue, Roland Barthes, Alain Robbe-Grillet, and the Paradise of the Writerly Text, „Criticism” 1980, nr 2.

10 N. Wolf, Une littérature sans histoire. Essai sur le Nouveau Roman, Paris 1995, s. 75 . 
o ludzkim przywiązaniu do złożonych mechanizmów narracji. W słynnym literackim manifeście Robbe-Grilleta - Pour un nouveau roman (1963) czytamy między innymi:

Powieść jest dla większości jej amatorów - także dla krytyków - przede wszystkim „historią”. Prawdziwy powieściopisarz to ten, który potrafi „opowiadać historie”. [...] Pismo jest jedynie środkiem, manierą; treścią powieści, uzasadnieniem jej istnienia, tym, co znajduje się w jej głębi, byłaby więc jedynie historia, którą opowiada ${ }^{11}$.

Nieco dalej, nie godząc się na takie właśnie postrzeganie powieści, pisarz stwierdza w sposób cokolwiek apodyktyczny: „opowiadanie stało się niemożliwe"12, a wszelka narracja, która nie odnosi się sceptycznie do siebie samej, jest niechcianym spadkiem mieszczańskiej literatury XIX stulecia. W przytoczonych wcześniej słowach Barthes’a nie doszukamy się jednak ani takiego radykalizmu, ani tak daleko idących wezwań. Teoretyk nie zapomina o zastrzeżeniach i obawach, jakie może budzić nadmierne zaufanie narracji, ale jednocześnie pisze o niej jako „formie pożądanej”, nazywa ją „swoistym obiektem pragnienia” - i właśnie w tym kierunku, jak sądzę, zmierza myśl autora rozprawy Wokót narracyjnego zwrotu ${ }^{13}$.

Postrzeganie narracji jako „obiektu pragnienia”, a nawet jako wyrazu ludzkiej potrzeby porządkowania doświadczenia, ma, rzecz jasna, swoje negatywne i pozytywne konsekwencje. $\mathrm{O}$ zagrożeniu związanym $\mathrm{z}$ tak definiowaną narracją pisali między innymi Jean-François Lyotard oraz z nieco innej perspektywy - Jacques Lacan i Slavoj Žižek. Pierwszy $\mathrm{z}$ nich w Kondycji ponowoczesnej (wyd. fr. - 1979) poddaje krytyce tak zwane wielkie narracje, powoływane do życia przez instytucje bądź mechanizmy władzy w celu ideologicznego zawłaszczenia rzeczywistości. Z kolei Lacan, a za nim Žižek uwrażliwiają nas na zagrożenie, jakie narracja może mieć $\mathrm{w}$ procesie konstruowania tożsamości - pragnienie za-

11 A. Robbe-Grillet, Pour un nouveau roman, Paris 1968, s. 34.

12 Tamże, s. 37.

13 Okazuje się zatem, że ani manifesty zwolenników nouveau roman, godzące w spójność narracji, ani teorie strukturalistów, umniejszające znaczenie opowieści na rzecz pracy nad słowem bądź zdaniem, nie doprowadziły do całkowitego jej upadku. Ten moment kryzysu trafnie podsumował G. Herling-Grudziński w szkicu Nota o „chorobie powieści”, opublikowanym w paryskiej „Kulturze” w roku 1960: „Powieść nie jest chora i nie potrzebuje ani obfitych zastrzyków odżywczych z rąk ortodoksyjnych i rygorystycznych stróżów tradycji, ani głodowej diety przepisanej przez nowoczesnych reistów. Przeżywa najwyżej naturalne zaburzenia wieku i rozwoju, a to jeszcze nie powód, by ją zaraz kłaść do łóżka i zwoływać u jej wezgłowia konsylium doktorów literatury” (G. Herling-Grudziński, Nota o „chorobie powieści”, [w:] tenże, Dzieła zebrane, wyd. krytyczne pod red. W. Boleckiego, t. III, Kraków 2013, s. 139). 
chowania logicznego ciągu przyczynowo-skutkowego opowieści i jej teleologiczny charakter mogą bowiem prowadzić do zafałszowania ,ja”, do ukrycia tego, co dla nas - w sensie psychologicznym - niewygodne bądź niebezpieczne. Jak twierdzi Loba:

Narracja mogła jeszcze uchodzić w oczach Freuda za formę niewinną, naturalną, ale dla Lacana, psychoanalityka wyczulonego na struktury mowy, stała się już przeszkodą w dostępie do ja, pasmem języka naznaczonym białymi plamami kłamstwa. [...] Mimo że Lacan nigdy nie zrezygnował z myśli, którą można sformułować w następujący sposób: pisać ciągle na nowo własną historię, jego psychoanaliza jest ostrym sprzeciwem wobec narracji, a nawet jej oskarżeniem o zaciemnianie, maskowanie nierozwiązanych konfliktów. Podejście Lacanowskie wyżej od narracyjnego uporządkowania ceni nieciągłość, dramatyczność, przerywany i wymuszany dialog, metaforę (s. 96-98).

W ostatnim dziesięcioleciu XX stulecia siła tej antynarratywistycznej rewizji znacznie osłabła, do głosu doszli zaś badacze, których poglądy jak się wydaje - są dużo bliższe autorowi książki Wokót narracyjnego $z w r o t u$. Ze zbioru prac tych badaczy warto przywołać rozprawy Julii Kristevej oraz Paula Ricœura. Kristeva, w oryginalny sposób kontynuująca badania z pogranicza psychoanalizy oraz teorii literatury, przekonuje, iż tworzenie narracji, snucie opowieści nie jest tym, co zaciemnia nasze ,ja” i utrudnia dostęp do ukrytych treści psychicznych, ale - zupełnie na odwrót - to działalność sensotwórcza, niejednokrotnie wyrywająca nas z objęć choroby. Opowiadanie swojej historii, podkreśla Kristeva w rozmowie, którą przeprowadził z nią Dominique A. Grisoni, jest równoznaczne z próbą wydobycia się z milczenia, w którym pogrąża się człowiek dotknięty chorobą:

Mowa człowieka pogrążonego w depresji może być monotonna lub żywa, ale zawsze człowiek ten sprawia wrażenie, że nie wierzy w to, co mówi, że ta mowa nie wychodzi z niego, że jest jakby poza nim, ukryta w tajemnej krypcie tego niemego bólu. [...] Melancholia byłaby zatem odchyleniem bez nazwy, czystym jak kartka papieru. To my musimy przywrócić ją słowom i życiu ${ }^{14}$.

Człowiek unikający słowa, zaś w konsekwencji - stroniący od narracji, zaszywa się w milczeniu, odgradza od świata i skazuje na egzystencję w „otchłani smutku, [w] niewysławialnym bólu, który nas niekiedy ogarnia, często na długo, prowadząc do utraty smaku mowy, jakiegokolwiek działania, a nawet smaku życia"15. Jedynym ratunkiem w takiej sytuacji,

${ }^{14} \mathrm{Na}$ dnie duszy. Z Julia Kristeva rozmawia Dominique A. Grisoni, przeł. J.M. Kłoczowski, „Res Publica Nowa” 1994, nr 6, s. 5.

15 J. Kristeva, Czarne stońce. Depresja i melancholia, przeł. M.P. Markowski, R. Ryziński, wstęp M.P. Markowski, Kraków 2007, s. 5. 
zdaje się podpowiadać Kristeva, jest rozpoczęcie opowieści - o sobie, o świecie, o innych.

Z tych samych powodów - związanych z możliwością konstruowania tożsamości $\mathrm{w}$ akcie narracyjnym, akcie opowiadania - bliska Lobie jest również teoria zaproponowana przez Ricœura ${ }^{16}$. Poznański badacz podkreśla zresztą, w pełni słusznie - jak sądzę, że „najpoważniejszym w ostatnich dekadach podejściem do problemu narracji i wydarzenia były we Francji prace Paula Ricœura" (s. 46). Nic więc dziwnego, że autor książki Wokót narracyjnego zwrotu do Ricœura powraca chyba najczęściej i najchętniej, mimo iż francuski filozof nie był przecież reprezentantem psychoanalitycznej orientacji w badaniach poświęconych narracji (choć, przypomnijmy, Ricœur wielokrotnie zabierał głos w sprawach z psychoanalizą związanych, jest też autorem słynnej rozprawy De l'interprétation. Essai sur Sigmund Freud - wydanej we Francji w 1965 roku17; przekład polski pod tytułem $O$ interpretacji: esej o Freudzie ukazał się w roku 2008). W konsekwencji Ricœur staje się jednym z głównych bohaterów licznych rozdziałów książki Loby: Narracje o podmiocie (s. 22-26), Podmiot i fikcja (s. 41-45), Narracja $i$ historia (s. 45-50), Od formy do znaczenia (s. 53-55), Czas, pamięć, trauma (s. 55-62), Zapomnienie (s. 6468), Fikcyjne i fantazmatyczne światy a literatura (s. 112-113), Narracja (s. 134-137), Opór (s. 137-146)18, Uznanie (s. 167-170). Pozwalam sobie przywołać wszystkie te tytuły, ponieważ wymownie wskazują one na dwa problemy, które w myśli Ricœura są dla Loby kluczowe: pierwszy z nich dotyczy kwestii podmiotu oraz tożsamości narracyjnej, drugi - podjętego na nowo wysiłku powiązania narracji z rzeczywistością, a więc przywrócenia jej referencji. Oba zagadnienia wybrzmiewają $\mathrm{w}$ następujących stwierdzeniach:

16 Warto przypomnieć $\mathrm{w}$ tym miejscu, że Loba jest też autorem innych rozpraw, w których obszernie i precyzyjnie omawia zagadnienie tożsamości narracyjnej Ricœura zob. M. Loba, Narracja. Tożsamość. Opór, [w:] Horyzonty interpretacji. Wokót myśli Paula Ricœura, red. A. Grzegorczyk, M. Loba, R. Koschany, Poznań 2003; tenże, Narrative and the Question of the Subject in the French Thought of the 1990s, przeł. M. Zapędowska, [w:] Man within Culture at the Threshold of the 21st Century, red. E. Rewers, J. Sójka, Poznań 2001.

${ }^{17} \mathrm{Na}$ temat znaczenia książki Ricœura zob. np. R.J. Bernstein, Ricœur's Freud, „Études Ricœuriennes / Ricœur Studies” 2013, nr 1 (<http://ricoeur.pitt.edu/ojs/index.php/ ricoeur/article/view/163/76> [12.01.2015]); J. Strauser, Une difficulté de la philosophie: (Paul Ricœur et) la psychanalyse, „Le Portique. Revue de philosophie et de sciences humaines" 2011, nr 26 (<http://leportique.revues.org/2514> [12.01.2015]).

18 Ten rozdział wydaje się szczególnie interesujący, ponieważ Loba relacjonuje w nim wypowiedzi teoretyków nieufnych wobec narracji, kwestionujących nawet zasadność mówienia o tożsamości narracyjnej tak, jak czynił to Ricœur. W gronie sceptyków pojawili się tu Barthes oraz Kristeva, w gronie krytyków - de Man i Derrida. 
Nie wchodząc w szczegóły, bo ta teoria jest dość szeroko znana, przypomnę tylko, że po pierwsze, Ricœur przywrócił narracji jej zdolność opowiadania o rzeczywistości, czyli oddał jej utraconą bądź problematyczną dla poststrukturalistów referencyjność. [...] Po drugie, Paul Ricœur odkrył z pewnym zaskoczeniem, że refleksja nad czasem i narracją przywiodła go do kwestii tożsamości narracyjnej i otworzyła na nowo problematykę podmiotu. [...] Po trzecie, narracja u Ricœura nie polega tylko na zwykłym porządkowaniu lub poznawaniu rzeczywistości [...]. U autora Czasu i opowieści tożsamość opowiadającego nie wynika tylko z konfiguracji intrygi, układu przeżytych zdarzeń, jest także efektem zderzenia z językiem, z jego nieprzejrzystością, z gęstością słów (s. 25) ${ }^{19}$.

Rzeczywiście, sprawa pierwsza, co podkreśla Loba, jest dziś dobrze znana i obrosła już licznymi opracowaniami - także w języku polskim ${ }^{20}$. Kwestia druga wydaje się za to dużo mniej oczywista, a w natłoku tekstów inspirowanych poststrukturalizmem - wręcz prowokacyjna. Jednak Loba, powołując się na Ricœura, ale też w inteligentny sposób śledząc przemiany zachodnioeuropejskiej (bo nie tylko - francuskiej) teorii i uważnie obserwując to, co dzieje się wokół nas wszystkich (myślę tu np. o wypadkach politycznych, które zmuszają nas do krytycznego przemyślenia wszelkich ustaleń teoretycznych), stawia odważnie pytanie o związek słowa z rzeczywistością, o wzajemną zależność narracji i egzystencji $^{21}$. Wagę tego zagadnienia dobrze ilustruje spór, jaki Ricœur podjął w roku 2000 w książce La mémoire, l’histoire, l’oubli (przekład polski pod tytułem Pamięć, historia, zapomnienie ukazał się w 2006 roku) z tezami na temat historiografii głoszonymi przez Haydena White'a - Loba szczegółowo relacjonuje historię tej polemiki (zob. s. 46-50). Podczas gdy White zaciera różnicę między historią a fikcją, odmawiając tym samym pisarstwu historycznemu prawa do opisu świata i właściwie eliminując jego moc referencyjną,

19 Zacytowany fragment pochodzi z rozdziału Narracje o podmiocie, w którym Loba trafnie i słusznie dyskutuje z redukcyjnym ujęciem myśli Ricœura zaprezentowanym przez K. Rosner w artykule Narracja jako pojęcie filozofii współczesnej oraz przez A. Bielik-Robson w szkicu Stowo i trauma. Narracja, czas, tożsamość (oba teksty ukazały się w zbiorze Narracja i tożsamość. (1) Narracje w kulturze).

20 Zob. np. G. Lubowicka, Sumienie jako poświadczenie: idea podmiotowości $w$ filozofii Paula Ricœura, Wrocław 2000; B. Baszczak, Narracja i tożsamość: Paula Ricœura hermeneutyka antropologiczna, Zielona Góra 2010; B. Baszczak, Tożsamość człowieka a pojęcie narracji, „Analiza i Egzystencja. Czasopismo Filozoficzne” 2011, nr 14 (<http://usfiles. us.szc.pl/pliki/plik_1324374361.pdf> [12.01.2015]).

21 Tę zależność wyraźnie widać w sferach, którymi na ogół nie interesują się w swych pracach teoretycy i historycy literatury - np. w polityce, zarządzaniu, ekonomii. Loba doskonale opisuje ten fenomen w rozdziale „Storytelling”. Polityczne i ekonomiczne pożytki $z$ narracji (s. 69-83), przywołując m.in. książkę Ch. Salomona Storytelling, la machine à fabriquer des histoires et à formatter les esprits, Paris 2007. 
francuski filozof osłabia, redukuje możliwą obecność fikcji w piśmiennictwie historiograficznym, zwiększając jej twórczy potencjał w literaturze. Narracja historyczna zwraca się w kierunku świata i zdarzeń, których referencyjną zdolność przedstawiania zachowują znaki. Narracja literacka jest redeskrypcją doświadczenia i chociaż często odsuwa referencyjność na drugi plan, zawsze pozostaje odkrywczym odtworzeniem i poszerzeniem granic rzeczywistości (s. 50).

Ricœur przywraca więc słowo rzeczywistości, a życia ujmowanego w opowieść wcale nie definiuje - przez wzgląd na językowy charakter tej opowieści - jako oddalenia od świata, ale raczej jako integralny jego element (ten sam problem pojawia się w książce Loby także w innych kontekstach, niekoniecznie związanych z filozofią Ricœura - zob. np. s. 33). Co ciekawe, próba reintegracji języka i świata nie jest u Ricœura obarczona żadnym redukcjonizmem, pozwalającym na naiwny powrót do myśli o języku naturalnym, nieuwikłanym w mechanizmy tropologiczne. $\mathrm{Z}$ tego też powodu tożsamość narracyjna nie jest - Loba ma tu całkowitą rację - wyłącznie próbą ujęcia zmiennego doświadczenia w tryby mniej lub bardziej skodyfikowanej opowieści; tożsamość tę cechuje również pewien rodzaj dramatyzmu, wynikający z przeświadczenia, że droga do ,ja” nigdy nie jest prosta, ponieważ prowadzi ona przez nieprzezroczysty, a więc - wymagający interpretacji, język. To przeświadczenie doskonale wybrzmiewa we wstępnej części książki Ricœura $O$ sobie samym jako innym, odsyłającej czytelnika między innymi do uwag Friedricha Nietzschego:

Trzeba przyznać, że z wyjątkiem przypadku Herdera, filozofia podmiotowości całkowicie pomija zapośredniczenie językowe, umożliwiające jej przekazywanie argumentacji na temat ,jestem” i „myślę”. Kładąc nacisk na ten wymiar filozoficznego dyskursu, Nietzsche wyciąga na światło dzienne retoryczne strategie, ukryte, zapomniane, a nawet obłudnie stłumione i odrzucone w imię bezpośredniości refleksji ${ }^{22}$.

Narracji nie powinno się zatem traktować jedynie jako językowego schematu (trudno tu zresztą mówić o schematach, skoro językiem rządzi prawo metafory) ani jako kompensacji, fikcji dającej wytchnienie; stanowi ona, wprost przeciwnie, istotną część rzeczywistości i charakteryzuje ją duży potencjał epistemologiczny.

W konsekwencji powiedzieć można, że książka Loby daje czytelnikowi znacznie więcej, niż zapowiada jej autor. Rozprawa Wokót narracyjnego zwrotu to bowiem nie tylko kompetentnie zarysowana i opowiedziana z pasją historia psychoanalitycznych sporów o narrację i jej charakter. To

22 P. Ricœur, O sobie samym jako innym, przeł. B. Chełstowski, naukowo oprac. i wstępem poprzedziła M. Kowalska, Warszawa 2003, s. 22. 
nie tylko zbiór błyskotliwych interpretacji wybranych utworów. To także, a może przede wszystkim, wyzwanie rzucone współczesnej nauce o literaturze, zwłaszcza tej, która mniej lub bardziej bezkrytycznie pozostaje pod wpływem tracącego na sile poststrukturalizmu. Nie chodzi mi przy tym o to, że Loba zdobycze poststrukturalizmu odrzuca - tak przecież nie jest (poznański badacz z dużą swobodą porusza się w gąszczu pism Derridy i innych teoretyków wiązanych na ogół z French Theory). Zależy mi raczej na podkreśleniu faktu, iż robi to tak, jak robić powinien uważny czytelnik poststrukturalistów - nieufnie i bez wyznawczego zacięcia. To właśnie pozwoliło Lobie napisać książkę, będącą zarówno podręcznikiem (w dobrym sensie tego słowa) do historii narracji, jak również zaproszeniem do kontynuowania refleksji nad tym, czym snucie opowieści może być dla nas wszystkich. 